\title{
Behaviour of cell cultures from human amniotic fluid
}

\author{
LIS HASHOLT \\ From the Institute of Medical Genetics, University of Copenhagen, Denmark
}

\begin{abstract}
Summary. The growth pattern of cell cultures originating from 11 amniotic fluid specimens have been observed. From each specimen 2 to 12 primary cultures were set up. In most cases growth started simultaneously in the primary cultures originating from one sample. The primary cultures lasted from 7 to 30 days. A variation was found both between cultures from different pregnancies as well as among cultures obtained from single amniotic fluids.

The growth period from setting up the cultures until harvest of the cell lines for biochemical analysis ranged from 20 to 54 days. No connexion was noticed between the time spent in primary culture and the behaviour of the cell line before harvest. The effects of two types of serum (fetal calf serum and pooled human serum) on the behaviour of the cultures were compared. The cells grown in human serum were harvested a few days before those grown in fetal calf serum. The influence of different batches of medium was also examined; no significant effect on the growth pattern was found. The appearance of epithelial-like and fibroblast-like cells in cultures from 6 specimens was observed concurrently. At the time of harvest the cell lines originating from the same amniotic specimen contained the cell types in different proportions.
\end{abstract}

It has become evident that the growth pattern of amniotic fluid cell lines may vary to some extent during culture. These variations, due both to the composition of cell types and to environmental conditions, can be expected to influence the diagnostic result (Gerbie et al, 1972; Littlefield, 1971; Kaback, Leonard, and Parmley, 1971). Therefore, it is essential to get a thorough knowledge of the normal behaviour of amniotic fluid cell lines during culture.

Recently, Sutherland and Bain (1973) and Sutherland, Bauld, and Bain (1974) have reported a variation of the life span between amniotic fluid cell lines from different pregnancies as well as in cell lines obtained at different stages of gestation from the same pregnancy.

The present studies were undertaken in order to investigate the variation in the behaviour of series of cultures originating from single amniotic fluids and to see if such a variation may have any influence on the activity of the enzymes. The purpose of the present paper is to report the growth patterns of

Received 24 July 1975. the cultures, while the enzymatic analysis will be published elsewhere.

\section{Material and methods}

The material comprised 11 specimens of amniotic fluid obtained from normal pregnancies by transvaginal amniocentesis before inducing abortion. The mean gestational age was 15.1 weeks (range: 13 to 18 weeks).

Primary cultures were handled as described by Hahnemann (1972). Depending on the available number of cells, 2 to 12 parallel cultures from each specimen were set up in Leighton tubes. The cell lines were maintained in $30 \mathrm{ml}$ plastic flasks (Nunc, Denmark) with a growth surface area of $25 \mathrm{~cm}^{2}$. The medium was Eagles MEM with Hank's salt solution, supplemented with glutamine and with either $20 \%$ fetal calf serum (FCS) or $20 \%$ pooled human serum (HUM). Penicillin and streptomycin were added as antibiotic agents. FCS and Eagles MEM were obtained from Flow Laboratories, Scotland; HUM was produced by pooling serum from samples of $10 \mathrm{ml}$ coagulated venous blood.

Harvesting was done by trypsination of almost confluent cultures. The number of cells needed for biochemical analysis was $1.5-2.0 \times 10^{6}$. 
All cultures were examined under an inverted microscope three times a week; this means that the growth periods may be stated with an error of 0 to 2 days. All ages refer to the day since the culture was set up.

\section{Results}

Cell growth was observed after 5 to 15 days (mean 8.1 days) in 68 of the 72 primary cultures started. The 4 cultures which failed to grow were all cultured in FCS-medium; three of the cultures, originating from the same amniotic fluid, were infected.

To compare the effects of FCS and HUM, cell cultures from single specimens were cultured both in FCS-medium and in HUM-medium. The culture methods were otherwise identical. The initiation of growth and the duration of time until the first subculturing were similar in cultures supplied with
FCS and HUM, respectively (Table I). A sufficient number of cells for enzymatic analysis was obtained 5 days later in the FCS-cultured cell lines as compared to the HUM-cultured cell lines. The difference is statistically significant $(P<0.05)$ according to a Wilcoxon rank test (1970) performed on the data from the amniotic fluids which contribute to both sets of observations.

The growth data for the investigated amniotic fluid cell cultures are outlined in Table II. In all the primary cultures originating from the same amniotic fluid, growth was observed on the same day with two exceptions. The primary cultures from specimen 7 started growing between the 6 th and 15th day; 5 of 6 cultures stopped growing before they could be harvested. In specimen 8 all cultures showed growth on the 5 th day except one which was scored positive on the 12 th day.

TABLE I

BEHAVIOUR OF PRIMARY CULTURES AND CELL LINES CULTURED IN MEM SUPPLEMENTED WITH $20 \%$ FCS OR $20 \%$ HUM

\begin{tabular}{|c|c|c|c|c|c|c|c|}
\hline $\begin{array}{l}\text { Type of serum } \\
\text { added to MEM }\end{array}$ & $\begin{array}{l}\text { No. of } \\
\text { amniotic fluid } \\
\text { samples }\end{array}$ & $\begin{array}{c}\text { No. of } \\
\text { primary } \\
\text { cultures } \\
\text { investigated }\end{array}$ & $\begin{array}{c}\text { Days before } \\
\text { growth, mean } \\
\text { (range) }\end{array}$ & $\begin{array}{c}\text { No. of } \\
\text { primary } \\
\text { cultures } \\
\text { investigated }\end{array}$ & $\begin{array}{l}\text { Days before } \\
\text { 1' subculture } \\
\text { mean (range) }\end{array}$ & $\begin{array}{c}\text { No. of } \\
\text { cell lines } \\
\text { investigated }\end{array}$ & $\begin{array}{c}\text { Days before } \\
\text { biochem. } \\
\text { analysis, mean } \\
\text { (range) }\end{array}$ \\
\hline $\begin{array}{l}\text { FCS } \\
\text { HUM }\end{array}$ & $\begin{array}{l}11 \\
10\end{array}$ & $\begin{array}{l}26 \\
21\end{array}$ & $\begin{array}{c}8.3 \\
(5-12) \\
7.9 \\
(5-15)\end{array}$ & $\begin{array}{l}35 \\
25\end{array}$ & $\begin{array}{c}17.2 \\
(7-30) \\
17.1 \\
(9-28)\end{array}$ & $\begin{array}{l}25 \\
10\end{array}$ & $\begin{array}{c}29.7 \\
(22-36) \\
25.1 \\
(20-31)\end{array}$ \\
\hline
\end{tabular}

TABLE II

DATA ON PRIMARY CULTURES AND CELL LINES FROM 11 AMNIOTIC FLUID SPECIMENS

\begin{tabular}{|c|c|c|c|c|c|c|c|c|}
\hline $\begin{array}{l}\text { Amniotic } \\
\text { fluid } \\
\text { specimen } \\
\text { no. }\end{array}$ & $\begin{array}{l}\text { No. of } \\
\text { primary } \\
\text { cultures }\end{array}$ & $\begin{array}{l}\text { Type of } \\
\text { serum added } \\
\text { to medium }\end{array}$ & $\begin{array}{l}\text { No. of } \\
\text { primary } \\
\text { cultures } \\
\text { with } \\
\text { growth }\end{array}$ & $\begin{array}{l}\text { Days before growth } \\
\text { mean (range)t }\end{array}$ & $\begin{array}{l}\text { No. of } \\
\text { primary } \\
\text { cultures } \\
\text { sub- } \\
\text { cultured }\end{array}$ & $\begin{array}{l}\text { Days before } \\
\text { 1' subculture } \\
\text { mean (range)t }\end{array}$ & $\begin{array}{l}\text { No. of } \\
\text { cell lines }\end{array}$ & $\begin{array}{l}\text { Days before } \\
\text { biochemical } \\
\text { analysis, } \\
\text { mean (range) }+\end{array}$ \\
\hline $\begin{array}{r}1 \\
2 \\
3 \\
4 \\
5 \\
6 \\
7 \\
8 \\
9 \\
10 \\
11\end{array}$ & $\begin{array}{r}3 \\
2 \\
13 \\
5 \\
5 \\
3 \\
3 \\
3 \\
3 \\
3 \\
3 \\
3 \\
3 \\
3 \\
3 \\
2 \\
2 \\
4 * \\
4 \\
1 \\
1\end{array}$ & $\begin{array}{l}\text { FCS } \\
\text { HUM } \\
\text { FCS } \\
\text { FCS } \\
\text { HUM } \\
\text { FCS } \\
\text { HUM } \\
\text { FCS } \\
\text { HUM } \\
\text { FCS } \\
\text { HUM } \\
\text { FCS } \\
\text { HUM } \\
\text { FCS } \\
\text { HUM } \\
\text { FCS } \\
\text { HUM } \\
\text { FCS } \\
\text { HUM } \\
\text { FCS } \\
\text { HUM }\end{array}$ & $\begin{array}{r}3 \\
2 \\
12 \\
5 \\
5 \\
3 \\
3 \\
3 \\
3 \\
3 \\
3 \\
3 \\
3 \\
3 \\
3 \\
2 \\
2 \\
1 \\
4 \\
1 \\
1\end{array}$ & $\begin{array}{c}\text { 二 } \\
12.0 \\
7.0 \\
7.0 \\
= \\
= \\
- \\
8.0 \\
8.0 \\
6.0 \\
12.6(10-15) \\
5.0 \\
7.3(5-12) \\
7.0 \\
7.0 \\
7.0 \\
7.0 \\
7.0 \\
5.0\end{array}$ & $\begin{array}{r}3 \\
2 \\
12 \\
3 \\
5 \\
2 \\
3 \\
3 \\
3 \\
3 \\
3 \\
2 \\
3 \\
3 \\
2 \\
2 \\
2 \\
1 \\
4 \\
1 \\
1\end{array}$ & $\begin{array}{l}20.0(14-30) \\
12.0 \\
21.4(16-26) \\
9.7(7-11) \\
9.4(9-11) \\
16.0(15-17) \\
14.3(13-15) \\
12.6(10-15) \\
13.0 \\
14.6(11-18) \\
12.3(11-15) \\
13.0 \\
210 \\
24.5(21-28) \\
14.0 \\
14.0 \\
14.0 \\
16.5(11-23) \\
12.0 \\
9.0\end{array}$ & $\begin{array}{r}3 \\
2 \\
11 \\
\\
1 \\
1 \\
1 \\
2 \\
2 \\
1 \\
1 \\
2 \\
2 \\
2 \\
1 \\
2 \\
1\end{array}$ & $\begin{array}{l}30.0(27-36) \\
23.0(20-26) \\
31.7(26-34) \ddagger \\
= \\
22.0- \\
22.0 \\
22.0 \\
22.5(22-23) \\
28.0 \\
260 \\
30.0 \\
36.0 \\
26.0- \\
26.0(25-27) \\
38.0 \\
27.5(24-31) \\
32.0\end{array}$ \\
\hline Total & 72 & & 68 & & 60 & & 35 & \\
\hline
\end{tabular}

* Growth was not started in 3 primary cultures from this sample due to infection.

† Range stated unless all equal.

‡ Omitting one epithelial-like cell line harvested after 54 days (see text). 
The time spent in primary culture varied both between cultures from different pregnancies as well as among cultures obtained from single amniotic fluids. Thus, the first subculturing, i.e. when a cell line arises from a primary culture, was performed between the 7th and 30th day. Since FCS and HUM did not appear to have a differential effect on the growth of primary cultures, these cultures can be compared regardless of the kind of serum supplied to the medium. Parallel primary cultures could only be subcultured on the same day in one case (9). In the remaining cases the range was from 4 to 18 days (Table II).

TABLE III

INFLUENCE OF DIFFERENT BATCHES OF MEDIUM ON CELL GROWTH

\begin{tabular}{c|c|c|c|c}
\hline $\begin{array}{c}\text { Culture } \\
\text { medium } \\
\text { batch no. }\end{array}$ & $\begin{array}{c}\text { Amniotic } \\
\text { fluid } \\
\text { sample no. }\end{array}$ & $\begin{array}{c}\text { * Range of } \\
\text { days before } \\
\text { growth }\end{array}$ & $\begin{array}{c}\text { * Range of } \\
\text { days before } \\
\text { 1' subculture }\end{array}$ & $\begin{array}{c}\text { * Range of } \\
\text { days before } \\
\text { biochemical } \\
\text { analysis }\end{array}$ \\
\hline 109 & 6 & 8 & $11-18$ & $26-28$ \\
109 & 8 & $5-12$ & $21-28$ & 36 \\
109 & 9 & 7 & 14 & $25-27$ \\
68 & 1 & - & $12-30$ & $20-36$ \\
135 & 10 & 7 & $11-23$ & $24-38$ \\
\hline
\end{tabular}

* Range stated unless all equal.

Thirty-six cell lines originating from 10 different pregnancies were cultured until they could be harvested for enzymatic determination. A sufficient number of cells for this purpose was obtained after 20 to 31 days (mean 25 days) in HUM-cultured cell lines, and after 22 to 36 days (mean 30 days) in the cell lines cultures in FCS. Four parallel cell lines from one sample (9) were harvested within 2 days; the greatest difference between parallel cell lines was 9 days. One cell line (from specimen 2) was considered separately (Table II), since it was growing very slowly and was dominated by epithelioid cells throughout the life span.

The morphology of the cells, epithelial-like or fibroblast-like, was registered concurrently in 28 cultures originating from 6 samples. The primary cultures contained predominantly epithelial-like cells, but contained fibroblast-like cells to a varying extent.

After 1 to 2 subcultivations the pattern changed as the fibroblast-like cells became more frequent. In 14 cell lines which were followed further the fibroblast-like cell type predominated after 4 to 7 passages.

Five amniotic fluid specimens were compared to examine whether the growth pattern varies, when different batches of medium are used (Table III).
The growth characteristics of the cultures (start of growth, first subculture, harvest of the cells) did not deviate any more in cultures grown in different batches of medium than in the cultures grown in the same batch.

\section{Discussion}

With two exceptions growth started simultaneously in parallel cultures from single amniotic fluids. One of these may be disregarded because the cells showed poor growth from the beginning and degenerated at an early stage. The difference between cultures from different pregnancies was about three days.

For the total material, the time until first subculture varied from 7 to 30 days. This is of the same order of magnitude as found by Sutherland et al (1974), whose primary cultures obtained from different pregnancies were subcultured after 18 to 41 days. The earlier subculturing of our material is possible because of a difference in the methods used. In the present material there was a distinct difference between the cultures from the most extreme specimens; thus, the first subculturing could be carried out after 9 days (range 7 to 11) in the fastest growing specimen and after 22 (range 21 to 28 ) days in the slowest one. Time in primary culture also varied within parallel cultures, the smallest difference being 2 days and the greatest 18 days. Sutherland and Bain (1973) found as much variation in the growth pattern of cell lines from amniotic fluids collected at different stages of a single pregnancy as they did in cell lines from different pregnancies. In the present material I found a variation of the growth pattern among parallel cultures as well as between cultures from different pregnancies. Furthermore, the growth characteristics of a cell line are independent of the behaviour of the primary culture.

When amniotic-fluid cells are cultured 20 to $30 \%$ FCS is usually added to the synthetic medium because the fetal calf serum is supposed to contain a growth stimulating factor (Nadler, 1969). Nelson and Emery (1973) have compared the effects of FCS and bovine calf serum but did not find a significant difference. In the present study FCS and HUM were compared, and it was found that cells cultured in HUM supplemented medium could be harvested 5 days earlier than cells cultured in FCS-medium. It will be of interest to know if this difference is reflected in the enzymatic activity, as demonstrated by Ryan, Lee, and Nadler (1972) in regard to different tissue culture media. Five different batches of culture medium were not found to have a significant effect on the growth pattern of the cultures. 
It should be stressed that parallel cell lines contain the epithelioid and fibroblast-like cell types in different proportions at the time of harvest. This is important as it may influence the enzyme assays. Thus, Gerbie et al (1972) have shown that histidase is found almost exclusively in the epithelial-like cells and cystathionine synthetase almost exclusively in the fibroblast-like cells.

I am greatly indebted to the personnel of the obstetric departments of the Øresundshospital and Bispebjerg hospital from which the material for this study was received and also to Dr Elisabeth Pilvang at the Municipal hospital of Copenhagen for having supplied the human serum.

I wish to thank Minna Jensen, Anja Boesen, and Elsebeth Lund Christensen for their skilful technical assistance.

\section{REFERENCES}

Gerbie, A. B., Melancon, S. B., Ryan, C., and Nadler, H. L. (1972). Cultivated epithelial-like cells and fibroblasts from amniotic fluid: their relationship to enzymatic and cytologic analysis. American fournal of Obstetrics and Gynecology, 114, 314-320.
Hahnemann, N. (1972). Possibility of culturing foetal cells at early stages of pregnancy. Clinical Genetics, 3, 286-293.

Kaback, M. M., Leonard, C. O., and Parmley, T. H. (1971). Intrauterine diagnosis: comparative enzymology of cells cultivated from maternal skin, fetal skin, and amniotic fluid cells. Pediatric Research, 5, 366-371.

Littlefield, J. W. (1971). Problems in the use of cultured amniotic fluid cells for biochemical diagnosis. Birth Defects: Original Article Series, 7, No. 5, 15-17. The National Foundation-March of Dimes, New York.

Nadler, H. L. (1969). Prenatal detection of genetic defects. Fournal of Pediatrics, 74, 132-143.

Nelson, M. M. and Emery, A. E. H. (1973). Amniotic fluid cell cultures. Fournal of Medical Genetics, 10, 19-22.

Ryan, C. A., Lee, S. Y., and Nadler, H. L. (1972). Effect of culture conditions on enzyme activities in cultivated human fibroblasts. Experimental Cell Research, 71, 388-392.

Sutherland, G. R. and Bain, A. D. (1973). Antenatal diagnosis of inborn errors of metabolism: tissue culture aspects. Humangenetik, 20, 251-255.

Sutherland, G. R., Bauld, R., and Bain, D. J. (1974). Observations on human amniotic fluid cell strains in serial culture. Fournal of Medical Genetics, 11, 190-195.

Uhlendorf, W. B. (1971). Usage of amniotic fluid reliability of diagnostic procedures. Early diagnosis of human genetic defects. In Fogarty International Centre Proceedings, No. 6. (Publication from international congress in Bethesda, Maryland, 1970. Ed. by Maureen Harris.)

Wilcoxon, F. (1970). Rank Tests, Documenta Geigy, 7th ed., p. 192. J. R. Geigy S.A., Basle. 